\title{
Effect of Carbon, Nitrogen Sources and Abiotic Stress on Phosphate Solubilization by Bacterial Strains Isolated from a Moroccan Rock Phosphate Deposit
}

\section{Ilham Mardad ${ }^{1,2 *}$, Aurelio Serrano ${ }^{2}$ and Abdelaziz Soukri ${ }^{1}$}

'Laboratory of Physiology and Molecular Genetics (LPGM), Department of Biology, University Hassan II, Faculty of Sciences Ain Chock, Km 8 route d'El Jadida, B.P. 5366 Mâarif. Casablanca, Morocco

${ }^{2}$ Instituto de Bioquímica Vegetal y Fotosíntesis (CSIC-Universidad de Sevilla), Centro de Investigaciones Científicas Isla de la Cartuja, Américo Vespucio 49, 41092-Sevilla, Spain

\begin{abstract}
Experiments were conducted to evaluate the solubilization of tri-calcium phosphate (TCP) by phosphatesolubilizing bacterial isolates PSB 4, 5 and 6 identified as Enterobacter sp., Bacterium DR172, and Enterobacter hormaechei, respectively, in addition to Acinetobacter sp. used as a positive control strain. The study was carried out in culture media using different carbon and nitrogen sources, and under different abiotic stress conditions such as high salt, $\mathrm{pH}$, and temperature. The effect of EDTA on growth was also tested. Organic acids produced by the PSB isolates were also determined by reverse phase HPLC. The isolates behave differently with different types of $\mathrm{N}$ - and $\mathrm{C}$-sources and seem to adapt to different conditions, with glucose significantly promoting TCP solubilization in all cases. The highest production of orthophosphate $\left(866 \mathrm{mg} \cdot \mathrm{L}^{-1}, \mathrm{pH} 3.2\right)$ was showed by Enterobacter hormaechei using glucose as $\mathrm{C}$-source, $\left(\mathrm{NH}_{4}\right)_{2} \mathrm{SO}_{4}$ as $\mathrm{N}$-source, at $37^{\circ} \mathrm{C}$ and $\mathrm{pH} 7$, and without any addition of EDTA. The solubilized phosphate also did attaint $110.71 \%$ in comparison with control when sorbitol was used as a C-source by Bacterium DR172. We also noticed a decrease in $\mathrm{pH}$ due to the organic acids secreted to the medium. Newly carboxylic acids were identified to be produced by these strains in addition to others previously identified, 2 ketogluconic acid was found when galactose was used as a C-source for all isolates except for Acinetobacter sp. which secreted lactic, glutaric and glucuronic acids. Analysis of the Solubilization Index (SI) of the bacterial strains at different temperatures revealed different effectiveness to degrade and assimilate TCP, the SI being maximal at $25^{\circ} \mathrm{C}$ for the three isolates (4.17, 3.83 and 4.44, for PSB4, 5 and 6), whereas for Acinetobacter sp. the highest SI (3.83) was achieved at $30^{\circ} \mathrm{C}$.
\end{abstract}

Keywords: Phosphate solubilization; Stress; Carbon source; Nitrogen source; Enterobacter; Acinetobacter

\section{Introduction}

In soils, maintaining high level of nitrogen $(\mathrm{N})$ and phosphorus $(\mathrm{P})$, the two most limiting nutrients factors remains a major challenge to ecologists and land managers, because improving soil fertility is one of the most common tactics to increase agricultural and forest production. Under diverse soil and agro-climatic conditions, the organisms with phosphate solubilizing (PS) abilities have proved to be an economically sound alternative to the more expensive superphosphates and possess a greater agronomic utility. Indeed, the microbial system can siphon out appreciable amounts of nutrients. The crop microbial ecosystem can thus be energized in sustainable agriculture with a considerable ecological stability and a good environmental quality.

Most PSMs dissolve poorly soluble soil phosphates by the acidification of the environment through organic acids secretion [13]. A continuous exploration of the soil microorganisms' natural biodiversity and the optimization/manipulation of microbial interactions in the rhizosphere represent a prerequisite step to develop more efficient microbial inoculants with phosphorus solubilizing ability [4].

In the alkaline soils, salt concentrations and $\mathrm{pH}$ may be as high as $2 \%$ and 10.5 , and temperatures may range between $35-45^{\circ} \mathrm{C}$ [5].

These conditions may lead to poor PSB growth and survival. In these soils, the available P is poor, and PSB use as bioinoculants the most appropriate solution. However, detailed studies have not been fully made on PSB isolated from alkaline soils, PSB availability in the majority of soils [6,7].

However, their performance is severely influenced by environmental factors especially under stress conditions [8,9]. To understand phosphate solubilization by PSB isolated from Moroccan Phosphate stock piles, an understanding of the physiology of these organisms, under stressed conditions is required. PSB, with the genetic potential or increased tolerance to high salt, high $\mathrm{pH}$, and high temperature, could enhance production of food and forage in different regions in the world.

Therefore, the objective of this study was to characterize and to evaluate the capacity of the PSB strains from Moroccan phosphate stock piles, to solubilize phosphates under stress conditions, at high salt concentration and temperature, low $\mathrm{pH}$, and EDTA addition.

\section{Materials and Methods}

Phylogenetic analysis of the PSB isolated from Moroccan phosphate stock piles by alignment with $16 \mathrm{~S}$ rDNA sequences

The phosphate solubilizing bacterial isolates PSB6, PSB4 and

*Corresponding author: Ilham Mardad, Laboratory of Physiology and Molecular Genetics (LPGM), Department of Biology, University Hassan II, Faculty of Sciences Ain Chock, Km 8 route d'El Jadida, B.P. 5366 Mâarif. Casablanca, Morocco, Tel: +212660768709; Fax: +212522230674; E-mail: mardadilham@yahoo.fr

Received January 08, 2014; Accepted January 26, 2014; Published February 04, 2014

Citation: Mardad I, Serrano A, Soukri A (2014) Effect of Carbon, Nitrogen Sources and Abiotic Stress on Phosphate Solubilization by Bacterial Strains Isolated from a Moroccan Rock Phosphate Deposit. J Adv Chem Eng 1: 102. doi: 10.4172/20904568.1000102

Copyright: @ 2014 Mardad I, et al. This is an open-access article distributed under the terms of the Creative Commons Attribution License, which permits unrestricted use, distribution, and reproduction in any medium, provided the original author and source are credited. 
PSB5, identified respectively as Enterobacter hormaechei (NCBI accession number: HM218110.1), Enterobacter sp. (NCBI accession number GQ284539.1) and Bacterium sp. (NCBI accession number: EU603515.1) [10] isolated from Rock Phosphate mine deposits were used for this research, in addition to the Acinetobacter sp. strain used as a positive control. The multiple alignments were constructed with the software package CLUSTAL X version 2.1. Evolutionary relationships were inferred using the Neighbor-Joining method. The bootstrap consensus tree inferred from 1000 replicates is presented. The tree is drawn to scale, with branch lengths in the same units as those of the evolutionary distances used to infer the phylogenetic tree. The evolutionary distances were computed using the Maximum Composite Likelihood method and are in the units of the number of base substitutions per site. All positions containing gaps and missing data were eliminated from the dataset (Complete deletion option). There were a total of 1447 positions in the final dataset. Phylogenetic analyses were conducted in MEGA4 [11].

\section{Bacterial strains and culture conditions}

The PSB strain designed as PSB4 for Enterobacter sp., PSB5 for Bacterium DR172, and PSB6 for Enterobacter hormaechei, in addition to Acinetobacter sp. were grown on the National Botanical Research Institute's Phosphate growth medium (NBRIP medium) [12], with tricalcium phosphate as the sole $\mathrm{P}$ source used to study the effect of variation of carbon and Nitrogen sources on the P solubilization and also to evaluate their limits of growth and solubilization under stress conditions (high salt concentration, $\mathrm{pH}$, temperature and EDTA addition). The phosphate solubilization by the 4 isolates was monitored up to 7 days in NBRIP medium at $30^{\circ} \mathrm{C}$ for the $3 \mathrm{PSB}$ and at $37^{\circ} \mathrm{C}$ for Acinetobacter sp. without salt $(\mathrm{NaCl})$ at $\mathrm{pH} 7$.

In broth, phosphate solubilization quantitative estimation was carried in Erlenmeyer's with $150 \mathrm{~mL}$ of NBRIP medium, inoculated with approximately $2 \times 10^{8} \mathrm{ufc}^{-1} \mathrm{ml}^{-1}$, from a 24 hours inoculum of Luria Bertani Broth (LB) including calcium triple phosphate (TCP) at concentration of $1 \%$.

\section{Growth under stressed conditions}

The strain's effects of carbon and nitrogen on phosphate solubilization were tested on the NBRIP medium, which unless stated contained per liter: glucose Glucose, $10 \mathrm{~g} ; \mathrm{Ca}_{3}\left(\mathrm{PO}_{4}\right)_{2}, 5 \mathrm{~g} ; \mathrm{MgCl}_{2} .6 \mathrm{H}_{2} \mathrm{O}$, $5 \mathrm{~g} ; \mathrm{MgSO}_{4} .7 \mathrm{H}_{2} \mathrm{O}, 0.25 \mathrm{~g} ; \mathrm{KCl}, 0.2 \mathrm{~g}$ and $\left(\mathrm{NH}_{4}\right)_{2} \mathrm{SO}_{4}, 0.1 \mathrm{~g}$ and the $\mathrm{pH}$ was adjusted to $\mathrm{pH}$ 7.0.

To assess the carbon source effect, glucose was replaced by galactose, lactose, maltose, fructose, mannitol, sucrose or sorbitol in the NBRIP. To study the nitrogen source effect, $\left(\mathrm{NH}_{4}\right)_{2} \mathrm{SO}_{4}$ was replaced by the nitrogen sources: $\left(\mathrm{NH}_{4}\right)_{2} \mathrm{NO}_{3}, \mathrm{KNO}_{3}, \mathrm{Ca}\left(\mathrm{NO}_{3}\right)_{2}$ and $\mathrm{NaNO}_{3}$ in the NBRIP. The effects of salt $(\mathrm{NaCl}), \mathrm{pH}$, temperature, and disodium salt of ethylene diamine tetra acetic acid (EDTA) on the solubilization of phosphate were tested by growing the strains on NBRIP containing various $\mathrm{NaCl}$ concentrations $(2.5,5,7.5$ and $10 \%) ; \mathrm{pH}(8,9,10,11$ and 12) adjusted with $0.1 \mathrm{M} \mathrm{NaOH}$, different temperatures $(25,30,37$ and $\left.45^{\circ} \mathrm{C}\right)$ and EDTA concentrations $\left(0.5,1,1.5,2.5,5,7.5\right.$ and $\left.10 \mathrm{mg} \mathrm{ml}^{-1}\right)$. Autoclaved, uninoculated batch cultures served as negative controls. The absolute value of the control referred to the amount of solubilized $\mathrm{P}\left(\mathrm{mg} \cdot \mathrm{mL}^{-1}\right)$ by each experimented strain.

\section{Analytical methods}

The strains were harvested by centrifugation at $13000 \mathrm{rpm}$ for 10 min, using a microcentrifuge Eppendorf model 5415C. The final growth medium $\mathrm{pH}$ was monitored using a JENWAY $3505 \mathrm{pH}$ meter equipped with a glass electrode. In the culture supernatant, the phosphate concentration was estimated colorimetrically using the molybdate blue normalized method according to French standard [13]. The values obtained with the uninoculated controls were always subtracted from their respective treatments.

\section{Solubilization Index estimation at different temperatures}

The abilities of the isolated bacteria to solubilize TCP at different temperatures were investigated. The sterilized NBRIP agar medium, containing insoluble $\mathrm{Ca}_{3}\left(\mathrm{PO}_{4}\right)_{2}$ at $5 \mathrm{~g} \cdot \mathrm{l}^{-1}$ as the only source of phosphate were used. The Petri plates were inoculated with the four PSB bacteria, and then incubated at different temperatures $\left(25,30,37,45^{\circ} \mathrm{C}\right)$ for 2 weeks and growth assessed visually. The solubilization index was determined by measuring the halo (clear zone) diameter and the colony diameter (CD), using the formula of Edi-Premono et al. [14]:

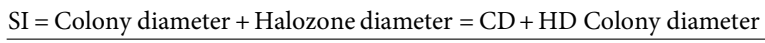
CD Colony diameter $\mathrm{CD}$

\section{HPLC Organic acid analysis}

For organic acids analysis, the PSB were grown on NBRIP medium where different sugars (glucose, fructose, galactose, maltose and sorbitol) were used at $10 \mathrm{~g} / \mathrm{l}$ as sole $\mathrm{C}$ sources. The bacteria were grown until the $\mathrm{pH}$ of the medium was reduced to 3.5 , and the 7-day culture supernatants were used for HPLC analysis. HPLC reverse-phase chromatography was used for the analysis of the organic acids produced by PSB strains in broth medium. The supernatant was collected from bacterial cultures that had been centrifuged at $13000 \mathrm{rpm}$ for $15 \mathrm{~min}$.

The samples were filtered through $0.2 \mu \mathrm{m}$ filter (Millipore, GTBP) and $20 \mu$ of the filtrates were injected to a HPLC Waters Lc Module I Plus, equipped with a UV-210 nm detector.

The organic acid separation was carried out on an Aminex HPX$87 \mathrm{H}$ column $(300 \times 7.8 \mathrm{~mm}$, Bio-Rad Laboratories, Inc.). The mobile phase flow (isoctratic) was at $5 \mathrm{mM} \mathrm{H}_{2} \mathrm{SO}_{4}$ constant flow rate of $0.6 \mathrm{ml} /$ min and the column was operated at $35^{\circ} \mathrm{C}$. Retention time (RT) of each signal was recorded at $210 \mathrm{~nm}$. The software used for HPLC analyses was Millennium 32 (Millipore), and the organic acids detected were identified by comparing their retention times and the peak areas of their chromatograms with those of standards (glutamic acid, gluconic acid, glucuronic acid, $a$-cetoglutaric acid, citric acid, 2 cetogluconic acid, galacturonic acid, oxaloacetic acid, malic, maleic, pyruvic, lactic, glycolic, glutaric, succinic, fumaric and acetic acid).

\section{Results and Discussion}

\section{PSB phylogenetic analysis}

The three PSB strains showed close phylogenetic relationships, as they belong to the same Enterobacteriaceae group (Figure 1). Enterobacter hormaechei subsp. steigerwaltii NM23-1 (PSB6) is a member of the Enterobacter cloacae complex, whereas PSB4 was identical to Enterobacter sp. TSSAS2-48 and PSB5 was identified as the unclassified bacterial strain named Bacterium DR172.

Isolations of bacterial strains belonging to this family have already been obtained from various soils and found to have inorganic phosphate (IP) solubilizing abilities [15-19], in addition to the genus Acinetobacter sp., which is used as a positive control in the present study. 

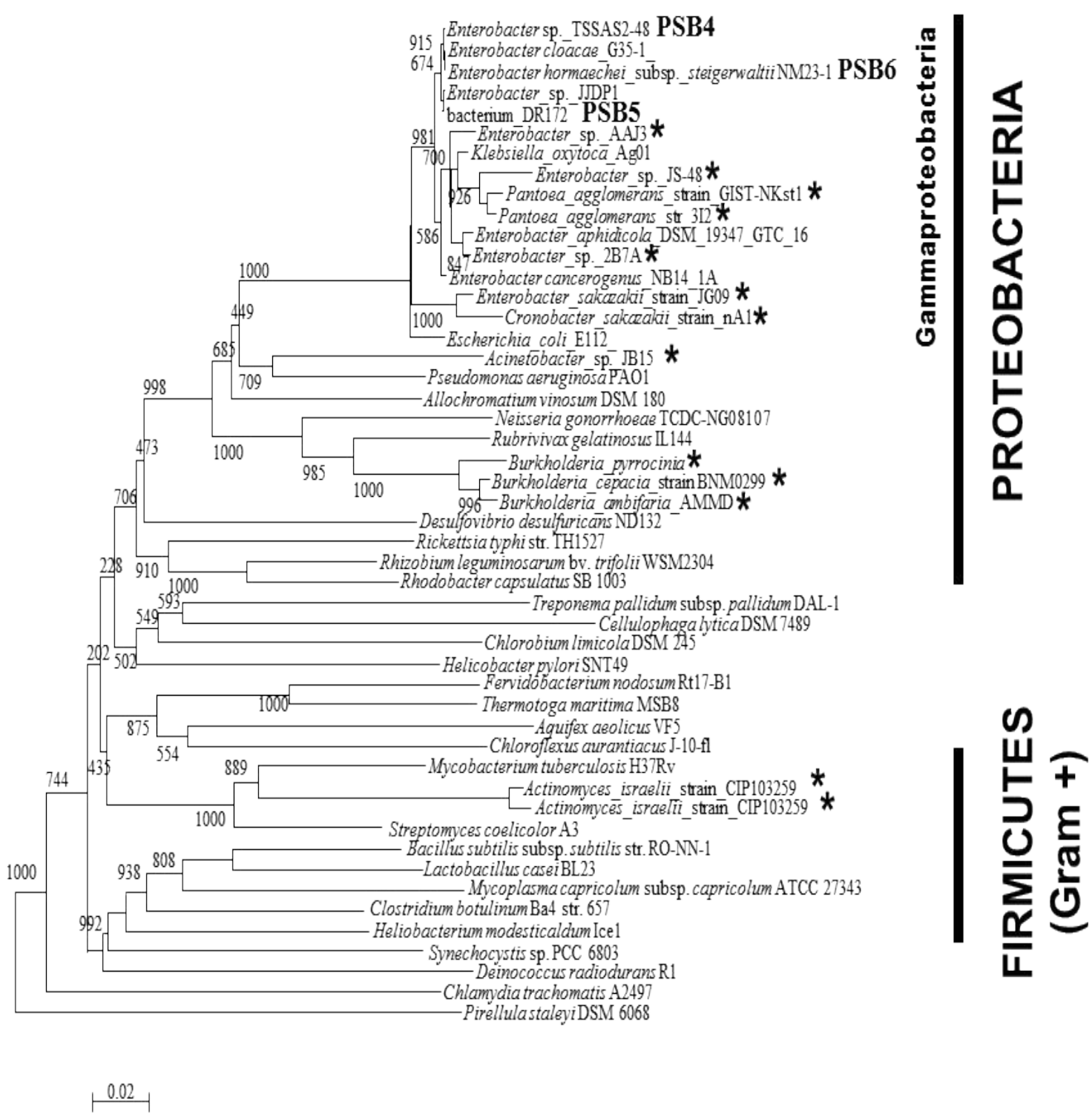

Figure 1: Neighbour-Joining phylogenetic tree based on 16S ribosomal RNA gene sequences of PSB strains isolated from Moroccan phosphate deposit studied in this work and other selected bacterial strains representative of main bacterial phylogenetic groups. PSB6 was identified as Enterobacter hormaechei subsp. Steigerwaltii NM23-1 a member of the Enterobacter cloacae complex; PSB4 was identical to Enterobacter sp. TSSAS2-48 and PSB5 was identified as a previously unclassified bacterial strain named Bacterium DR172. The three PSB strains show close phylogenetic relationships, as they belong to the same Enterobacteriaceae group. Other reported PSB strains are indicated with asterisks. Note that most PSB strains belong to to Gammaproteobacteria, although some Alphaproteobacterial and Firmicutes species have been reported as PSB strains.

\section{Carbon and nitrogen sources effects on phosphate solubilization}

The solubilization activity was estimated in the presence of eight carbon and Four nitrogen sources, by replacing glucose and $\left(\mathrm{NH}_{4}\right)_{2} \mathrm{SO}_{4}$, respectively (Table 1).

The four strains produced organic acids which reduced the growth medium $\mathrm{pH}$ from neutral to acidic values. The acid concentrations varied from 74 to $253 \mathrm{mM}$, according to the studied strain. The $\mathrm{pH}$ decrease was correlated with organic acids production [20]. However the synthesized organic acids varied according to the carbon source used. Indeed, while strains PSB 6 and the Acinetobacter produced the maximum of acids while assimilating glucose, PSB 5 and 4 produced the maximum of acids on galactose, then on glucose.

All strains demonstrated diverse levels of phosphate solubilization activity in the presence of various carbon and nitrogen sources. Among the four strains PSB6 proved to be the most efficient strain considering its ability to solubilize $\mathrm{P}$ utilizing a wide range of carbon and nitrogen sources at high concentration of orthophosphate liberated (Table 1).

All the nitrogen sources were utilized for phosphate solubilization by our strains. The results revealed that there is a change in the phosphate solubilization when the ammonium and different sources of nitrates were used as nitrogen source (Table 1). 


\begin{tabular}{|c|c|c|c|c|}
\hline \multirow{2}{*}{ Ingredients } & \multicolumn{4}{|c|}{ Phosphate solubilized en comparison with control (\%) } \\
\hline & PSB 6 & PSB5 & PSB4 & Acin \\
\hline Controla $^{a}$ & $100(3.35)$ & $100(3.75)$ & $100(3.60)$ & $100(3.55)$ \\
\hline Absolute value ${ }^{b}$ & $730.30 \pm 11.98$ & $570.49 \pm 11.44$ & $597.59 \pm 16.90$ & $671.59 \pm 16.69$ \\
\hline \multicolumn{5}{|l|}{ Carbon source ${ }^{c}$} \\
\hline Galactose & $93.15(3.41)$ & $97.23(3.7)$ & $86.46(3.8)$ & $77.33(3.83)$ \\
\hline Lactose & $49.88(4.31)$ & $45.59(4.25)$ & $43.58(4.4)$ & $41.12(4.19)$ \\
\hline Maltose & $84.66(4.33)$ & $96,29(3.66)$ & $80.06(4.03)$ & $56.23(4.16)$ \\
\hline Fructose & $112.46(3.52)$ & $104.25(3.6)$ & $92.31(3.68)$ & $18.84(4.52)$ \\
\hline Mannitol & $26.31(4.57)$ & $17.90(4.71)$ & $36.01(4.33)$ & $16.30(4.41)$ \\
\hline Sucrose & $30.04(4.49)$ & $17.18(4.76)$ & $34.06(4.30)$ & $17.15(4.44)$ \\
\hline sorbitol & $59.82(4.20)$ & $110.71(3.40)$ & $57.28(4)$ & $3.44(5.35)$ \\
\hline \multicolumn{5}{|l|}{ Nitrogen source $^{d}$} \\
\hline$\left(\mathrm{NH}_{4}\right)_{2} \mathrm{NO}_{3}$ & $78.34(3.50)$ & $60.04(4)$ & $70.21(3.71)$ & $45.47(4.10)$ \\
\hline $\mathrm{KNO}_{3}$ & $76.10(3.52)$ & $59(3.67)$ & $66.55(3.80)$ & $64.13(3.55)$ \\
\hline $\mathrm{Ca}\left(\mathrm{NO}_{3}\right)_{2}$ & $74.19(3.60)$ & $57.30(4.22)$ & $60.02(3.92)$ & $63.44(3.56)$ \\
\hline $\mathrm{NaNO}_{3}$ & $24.23(4.42)$ & $56(4.45)$ & $30(4.51)$ & $22.90(4.30)$ \\
\hline
\end{tabular}

aControl strains were grown at $30^{\circ} \mathrm{C}$ for our PSB and at $37^{\circ} \mathrm{C}$ for Acinetobacter sp. during 3 days in National Botanical Research Institute's Phosphate growth medium (NBRIP) which contained per liter: Glucose, $10 \mathrm{~g} ; \mathrm{Ca}_{3}\left(\mathrm{PO}_{4}\right)_{2}, 5 \mathrm{~g} ; \mathrm{MgCl}_{2} \cdot 6 \mathrm{H}_{2} \mathrm{O}, 5 \mathrm{~g} ; \mathrm{MgSO}_{4} \cdot 7 \mathrm{H}_{2} \mathrm{O}, 0.25 \mathrm{~g} ; \mathrm{KCl}, 0.2 \mathrm{~g}$ and $\left(\mathrm{NH}_{4}\right)_{2} \mathrm{SO}, 0.1 \mathrm{~g}$ at pH 7 . Autoclaved, uninoculated batch cultures served as negatif controls.

${ }^{\mathrm{b}}$ The absolute value of phosphate solubilization $\left(\mathrm{mg} . \mathrm{L}^{-1}\right)$ of control corresponding to $100 \%$. Values are means \pm S.D. for triplicate samples.

'Glucose in the NBRIP was replaced by the carbon source as indicated.

${ }^{\mathrm{d}}\left(\mathrm{NH}_{4}\right)_{2} \mathrm{SO}_{4}$ in the NBRIP medium was replaced by the nitrogen source as indicated.

Table 1: Effect of various carbon and nitrogen sources on TCP solubilization by PSB4, PSB5, PSB6 and Acinetobacter sp.

The PSB were checked for their phosphate solubilization ability under stressed conditions by varying the salt concentration $(\mathrm{NaCl} ; 0$, 2.5 , and $5 \%)$ and $\mathrm{pH}(7,8$ and 9$)$ of the medium and incubating the plates at the optimum temperature or at $\left(30,37\right.$, and $\left.45^{\circ} \mathrm{C}\right)$ as indicated in Table 2.

\section{Influence of the variation of carbon source (C)}

After inoculation on NBRIP media with different bacterial strains previously pre-inoculated on LB liquid media plus TCP, we have noticed an increase in concentrations of orthophosphate released into the extracellular environment for all our PSB in control condition and noted as an absolute value for each Bacterium on Table 1.

Among the four bacterial strains, the PSB6 released a very high concentration of orthophosphate $730.30 \mathrm{mg} \mathrm{l}^{-1}$, followed by Acinetobacter sp. with $671.59 \mathrm{mg} \mathrm{l}^{-1}$. PSB4 and PSB5 liberated respectively $597.59 \mathrm{mg} \mathrm{l}^{-1}$ and $570.49 \mathrm{mg} \mathrm{l}^{-1}$. All bacteria have demonstrated varying degrees of solubility in the presence of various sources of carbon and nitrogen.

The PSB6 and PSB5 could use fructose as their best carbon source by producing respectively $112.46 \%$ and $104.25 \%$ of soluble phosphate, in addition to glucose which allows the production of $100 \%$ of orthophosphate by our 4 different bacterial strains.

In addition to fructose, the PSB5 had an exceptional preference for sorbitol as a carbon source, unlike PSB6 and PSB4 whose concentration of orthophosphate produced was reduced to almost half compared with cultures in the presence of glucose. While sorbitol was a poor carbon source for Acinetobacter sp. (3.44\%).

Fructose has been identified as the best carbon source for Rhodotorula minuta NCIM 3359 and Saccharomyces cerevisiae ATCC 9896 in cultures [21].

Glucose was found to be best carbon source followed by sucrose and galactose for phosphate solubilization by Pseudomonas striata [22]. Glucose and fructose are well understood by all species tested.
These results are consistent with the fact that these monosaccharides after phosphorylation are the major metabolites of glycolysis.

Mannitol and sucrose are also low carbon source for all our PSB strains. Lactose is a carbon source used by our bacteria in their phospho-solubilization although concentrations of orthophosphate released in this case are between 50 and $40 \%$ compared to control.

While galactose followed by maltose represent carbon sources sizeable by the different PSB used in this study, which could also be used to solubilize the TCP in the absence of glucose.

Aspergillus Niger could solubilize more $\mathrm{CaHPO}_{4}$ in the presence of maltose and mannitol then with sucrose in liquid culture medium [23]. In some studies, the two disaccharides, sucrose and maltose have been proven to be a good source of carbon during the solubilization of TCP [20].

In culture medium of Enterobacter aerogenes and in the presence of TCP with various carbon sources including: arabinose, fructose, galactose, sorbitol, mannitol, xylose, sucrose, maltose and lactose, a positive effect has been advanced on the activity of phosphosolubilization, except for xylose [24].

All monosaccharides are more effective in the solubilization of phosphate then disaccharides or polysaccharides and alcohols. The carbon source is required for the synthesis of cell material and the oxidation of carbon compounds. The use of $\mathrm{C}$ by an organism is dependent on its enzyme system, especially if it is naturally occurring or induced [25].

\section{Effects of various nitrogen $(\mathrm{N})$ forms on the phosphate solubilization}

Microorganisms behave differently in the presence of different sources of N. The efficiency of five different nitrogen sources on PS activity was studied.

Phospho-solubilization is related to the excretion of protons $\left(\mathrm{H}^{+}\right)$ that accompanies the breathing or the assimilation of $\mathrm{NH}_{4}^{+}[26]$. 


\begin{tabular}{|c|c|c|c|c|}
\hline \multirow{2}{*}{ Treatments } & \multicolumn{4}{|c|}{ Phosphate solubilization under different treatment } \\
\hline & PSB6 & PSB5 & PSB4 & Acin \\
\hline Control $^{\mathrm{a}}$ & $100(3.35)$ & $100(3.75)$ & $100(3.60)$ & $100(3.55)$ \\
\hline Absolute value ${ }^{b}$ & $730.30 \pm 11.98$ & $570.49 \pm 11.44$ & $597.59 \pm 16.90$ & $671.59 \pm 16.69$ \\
\hline \multicolumn{5}{|l|}{ Salt $(\mathrm{NaCl}, \mathrm{w} / \mathrm{v})$} \\
\hline 2.5 & $87.70(3.31)$ & $83.5(3.81)$ & $77.13(3.70)$ & $44.67(3.82)$ \\
\hline 5 & $66.28(3.55)$ & $65.2(3.98)$ & $60.36(3.88)$ & $37.27(4)$ \\
\hline 7.5 & $44.81(4.11)$ & $40.01(4.43)$ & $48.53(4.2)$ & $33.21(4.31)$ \\
\hline 10 & $12.53(4.96)$ & $11.60(4.82)$ & $11.07(4.74)$ & $9.04(5.09)$ \\
\hline \multicolumn{5}{|l|}{$\mathrm{pH}$} \\
\hline 8 & $86.22(3.51)$ & $70.13(4)$ & $75.34(3.63)$ & $68.77(3.5)$ \\
\hline 9 & $62.08(3.47)$ & $61.35(4.32)$ & $54.06(3.81)$ & $59.29(4.07)$ \\
\hline 10 & $60.62(3.49)$ & $45.85(4.54)$ & $46.27(4.09)$ & $50.69(4.11)$ \\
\hline 11 & $2.31(7.04)$ & $1.68(9)$ & $2.18(7.8)$ & $1.64(8)$ \\
\hline 12 & $1.13(9.70)$ & $0.19(10)$ & $0.27(10.8)$ & $0.60(10.08)$ \\
\hline \multicolumn{5}{|l|}{ Temperature $\left({ }^{\circ} \mathrm{C}\right)$} \\
\hline 25 & 100. $83(3.44)$ & $96.95(3.7)$ & $93.82(3.65)$ & 90.07 (3.62) \\
\hline 30 & $100.62(3.37)$ & $100.57(3.73)$ & $100.91(3.6)$ & $99.21(3.50)$ \\
\hline 37 & $118.62(3.20)$ & $84.19(3.79)$ & $102.16(3.57)$ & $101.19(3.55)$ \\
\hline 45 & $47.05(3.96)$ & $35.31(4.5)$ & $37.04(4.41)$ & $45.21(4)$ \\
\hline
\end{tabular}

aControl strains were grown for 3 days in National Botanical Research Institute' phosphate growth medium (NBRIP) which contained per liter : Glucose, $10 \mathrm{~g}$; Ca3(PO4), $5 \mathrm{~g} ; \mathrm{MgCl}_{2} .6 \mathrm{H}_{2} \mathrm{O}, 5 \mathrm{~g} ; \mathrm{MgSO}_{4} .7 \mathrm{H}_{2} \mathrm{O}, 0.25 \mathrm{~g} ; \mathrm{KCl}, 0.2 \mathrm{~g}$; and $\left(\mathrm{NH}_{4}\right)_{2} \mathrm{SO}_{4}, 0.1 \mathrm{~g}$ at $30^{\circ} \mathrm{C}$ for our PSB and at $37^{\circ} \mathrm{C}$ for Acinetobacter, in the presence of $0 \%$ salt $(\mathrm{NaCl})$ at $\mathrm{pH}$ 7. Autoclaved, uninoculated batch cultures served as negative controls. Final $\mathrm{pH}$ of the growth medium is given within the parentheses, and variation (S.D.) was within \pm 0.04 , for triplicate samples.

${ }^{b} T$ The absolute value of phosphate solubilization ( ) of control corresponding to $100 \%$. Values are means \pm S.D. for triplicate samples.

cNBRIP was modified with various amounts of salt $(\mathrm{NaCl}, \mathrm{w} / \mathrm{v}), \mathrm{pH}$ or temperature as indicated.

Table 2: Effect of salt, $\mathrm{pH}$ and temperature on TCP solubilization by PSB4, PSB5, PSB6 and Acinetobacter sp.

Ammonium addition in bacterial cultures increased the solubilization of $\mathrm{P}[27,28]$.

All sources of nitrogen were used by our bacterial strains to solubilize phosphate. The results showed that there was a change in the solubilization level when ammonium or different sources of nitrates were used as a source of $\mathrm{N}$ (Table 1). Our results are in agreement with the study of Nautiyal et al. [29] and unlike previous studies [30,31] we found that ammonium and nitrate sources are also effective for the solubilization of $\mathrm{P}$. In addition, ammonia is an important and necessary element in the solubilization of TCP by Aspergillus sp. and Penicillium sp. in liquid culture [32].

Ammonium nitrate, potassium nitrate or calcium sources are having a strong assimilation by our PSB, lowering the $\mathrm{pH}$ culture media, with a difference of assimilation of ammonium by Acinetobacter, which was reduced to $45.47 \%$. Other PSB studies attributed the difference in phosphate solubilization, when ammonium nitrate was used, to the presence of different mechanisms for the generation of acidity in culture $[27,33]$.

The presence of ammonium in the culture medium of Penicillium cyclopium had led to the development of inorganic acid by a clearing or extrusion of protons $[33,34]$. While a second mechanism did not need the presence of ammonium and probably involved the secretion of organic acid metabolites by phospho-solubilizing fungi $[27,35]$.

All nitrogen sources namely, the ammonium nitrate, potassium nitrate, calcium nitrate, sodium nitrate, which were found to be lower than ammonium sulfate in the context of the solubilization of TCP and RP by Enterobacter aerogenes [24]. All sources of nitrates have been effectively used by Pseudomonas fluorescens for the solubilization of TCP [20].

The solubilizing activity of TCP is influenced by the nitrogen compounds, which may be arranged in the following order: ammonium sulfate $>$ nitrate ammonium $>$ potassium nitrate $>$ calcium nitrate $>$ sodium nitrate, this result is consistent with the study of Karunai and Ravindran [36], who cited this same N sources order of importance during the solubilization of TCP by Bacillus subtilis.

Our bacteria have proven their ability to solubilize inorganic phosphate in a wide range of carbon and nitrogen sources. Thus, the nature of carbon and nitrogen source used by the micro-flora directly influences the nature and composition of organic acids produced and therefore the importance of the solubilization activity.

\section{Effect of high salt, high $\mathrm{pH}$ and high temperature on the phosphate solubilization}

To study the effect of high salt, high $\mathrm{pH}$ and high temperature on the phosphate solubilization activity of our PSB, the strains were grown in the presence of $\mathrm{NaCl}$ at different concentrations $(2.5 \%, 5 \%, 7.5 \%$ and $10 \%)$, high $\mathrm{pH}(8,9,10,11$ and 12$)$ and different temperatures $\left(25^{\circ} \mathrm{C}\right.$, $30^{\circ} \mathrm{C}, 37^{\circ} \mathrm{C}$ and $45^{\circ} \mathrm{C}$ ) (Table 2).

The four strains generally seem to adapt to different conditions. They showed various levels of $\mathrm{P}$ solubilization in the presence of salt, $\mathrm{pH}$ or high temperature (Table 2).

It seemed that the strains isolated from alkaline soils have the potential to solubilize $\mathrm{P}$ at high salt content, $\mathrm{pH}$ and high temperature. Among the four bacterial strains, the PSB6 proved to be the most effective strain to solubilize $\mathrm{P}$ in the presence of $10 \% \mathrm{NaCl}$, at $45^{\circ} \mathrm{C}$ and at pH 10 (Table 2).

All strains showed a significant decrease in the P solubilization, when the final $\mathrm{pH}$ of the medium was approximately 8.0 and above. By analyzing the solubilization degree at different temperatures we noticed that four bacterial strains adapt very well, we even have noted a significant increase in the solubilization at $37^{\circ} \mathrm{C}$ for PSB6 and PSB4. 
$30^{\circ} \mathrm{C}$ is the optimum temperature for all PSB except for Acinetobacter sp. whose optimal was at $37^{\circ} \mathrm{C}$, and where it could release $671.59 \mathrm{mg} . \mathrm{l}^{-1}$ of orthophosphate.

At this same temperature of $37^{\circ} \mathrm{C}$, we noted a strong release of soluble P by PSB6; the concentration has reached 866.29 mg. $1^{-1}$ higher than the previous concentration which was $730.30 \mathrm{mg} \cdot \mathrm{l}^{-1}$ at $30^{\circ} \mathrm{C}$. At $25^{\circ} \mathrm{C}$ (room temperature) the PSB6 dissolved as well the TCP.

At high temperature of $45^{\circ} \mathrm{C}$, the four bacteria were able to grow and thus dissolve the TCP in culture, although their degree of solubilization has significantly decreased compared to the optimal solubilization temperature (Table 2).

\section{$\mathrm{pH}$ variation}

In our study we observed changes in $\mathrm{pH}$ from neutral $7.0 \pm 0.2$ to acidic values in the presence of different sources of carbon and nitrogen, and under different stress conditions $\left(\mathrm{NaCl}, \mathrm{pH}, \mathrm{T}^{\circ}\right)$ results are recorded in Tables 1 and 2 .

The $\mathrm{P}$ released by the microorganisms was associated with reduction in $\mathrm{pH}$ of the culture medium, suggesting the production of organic acid [20-26,37-38]. The medium pH of PSB5, PSB4 and Acinetobacter sp. dropped slightly with $0.05,0.03$ and 0.05 unit in comparison with the control, when placed in culture at a temperature of $25^{\circ} \mathrm{C}, 37^{\circ} \mathrm{C}$ and $30^{\circ} \mathrm{C}$, respectively (Table 2 ) with concentrations of orthophosphate released, that were just over 100\% for PSB4 and PSB5 except for Acinetobacter sp. which the $[\mathrm{P}]$ released is at its maximum at the optimum temperature of $37^{\circ} \mathrm{C}$, in conclusion, the increase in incubation temperature also influenced the decrease in $\mathrm{pH}$ of the culture medium.

In similar studies, we found that the Phosphate solubilization by the Pseudomonas fluorescens, Bacillus megaterium and Azospirillum spp. was accompanied with $\mathrm{pH}$ reduction of the culture medium [39]. Maximum pH reduction was 2.8, 1.2 and 0.5 units for Pseudomonas fluorescens, Bacillus megaterium and Azospirillum lipoferum strain 137, respectively, when compared to control $\mathrm{pH}$ of 6.8 [40].

Also some fluctuations in $\mathrm{pH}$ during TCP solubilization in the presence of nitrogenous compounds ranged from 4.0 to 7.5 and for RP the $\mathrm{pH}$ ranged between 3.8 and 7.5 [36].

\section{The solubilization efficiency of the PSB in NBRIP agar me- dium at different temperatures}

The solubilization efficiency of the four bacterial strains was evaluated by calculating their indices after inoculating them in NBRIP agar at different temperature of $\left(25^{\circ} \mathrm{C}, 30^{\circ} \mathrm{C}\right.$ and $\left.37^{\circ} \mathrm{C}\right)$. The SI was calculated using the equation of Edi-Premono et al. [14].

Analysis of the SI of the 4 bacterial strains at different temperatures: $25^{\circ} \mathrm{C}, 30^{\circ} \mathrm{C}$ and $37^{\circ} \mathrm{C}$, revealed their effectiveness and their ability to degrade and assimilate the TCP in NBRIP under the different conditions (Tables 3-5). Solubilization Indices are calculated and for PSB6 we had a SI of 4.38 , for PSB4 it was about 4.14 . SI=3.70 and 3.83 were calculated for PSB5 and Acinetobacter sp. respectively at a temperature of $30^{\circ} \mathrm{C}$ (Table 4 ).

At room temperature $\left(25^{\circ} \mathrm{C}\right)$, the bacteria showed a SI slightly ahead of that recorded at $30^{\circ} \mathrm{C}$, and with a little more incubation time (14 days), except for PSB5 (after 12 days). The 3 PSB have presented the following SI: 4.17, 3.83 and 4.44 for PSB4, PSB5 and PSB6 respectively, while Acinetobacter sp. could record a SI of 3.7 (Table 3).

At a temperature of $37^{\circ} \mathrm{C}$, the SI reached was lower than that calculated for the four bacteria at $30^{\circ} \mathrm{C}$ and $25^{\circ} \mathrm{C}$, this is due to the fact that the plates kneaded incubated at $37^{\circ} \mathrm{C}$, quickly suffered a drying because of high temperature, despite the use of soft agar and the incubation in a humidified incubator (Table 5).

At a temperature of $45^{\circ} \mathrm{C}$, the bacteria were unable to solubilize the TCP on solid agar, barely visible halozone were perceived to naked eye. After the end of the incubation period, the NBRIP plates were sealed and kept at $4^{\circ} \mathrm{C}$. After a while, we noticed that even at $4^{\circ} \mathrm{C}$, the bacterial strains continued to solubilize TCP on plates until its complete consumption (Figure 2).

\section{EDTA effect on phosphate solubilization by the PSB}

The addition of $0.5 \mathrm{mg} \cdot \mathrm{ml}^{-1}$ of EDTA caused a decrease in the $\mathrm{P}$

\begin{tabular}{|c|c|c|c|c|c|c|c|c|}
\hline Incubation day SI at $\mathbf{2 5}^{\circ} \mathbf{C}$ & $\mathbf{1}$ & $\mathbf{2}$ & $\mathbf{4}$ & $\mathbf{6}$ & $\mathbf{8}$ & $\mathbf{1 0}$ & $\mathbf{1 2}$ & 3.80 \\
\hline PSB4 & 2.8 & 3.2 & 3.33 & 3.66 & 3.76 & 3.8 & 3.76 \\
\hline PSB5 & 2.8 & 3.2 & 3.8 & 3.5 & 3.5 & 3.83 \\
\hline PSB6 & 3.2 & 3.4 & 3.5 & 3.67 & 3.71 & 3.14 \\
\hline Aci & 2.4 & 2.8 & 3.2 & 3.6 & 3.44 & 3.5 \\
\hline
\end{tabular}

Table 3: Solubilization Index (SI) of the Phosphate Solubilizing Bacteria (PSB) at $25^{\circ} \mathrm{C}$.

\begin{tabular}{|c|c|c|c|c|c|c|c|c|}
\hline Incubation day & 1 & 2 & 4 & 6 & 8 & 10 & 12 & 14 \\
\hline $\mathrm{SI}$ at $30^{\circ} \mathrm{C}$ & 1 & 2 & 3 & 4 & 6 & 8 & 10 & 12 \\
\hline PSB4 & 2.4 & 2.8 & 3.2 & 3.4 & 3.17 & 3.5 & 3.83 & 4.14 \\
\hline PSB5 & 2.4 & 2.8 & 3.2 & 3.4 & 3.33 & 3.5 & 3.67 & 3.70 \\
\hline PSB6 & 2.8 & 3.4 & 4 & 3.83 & 4 & 3.92 & 3.93 & 4.38 \\
\hline Aci & 2.8 & 3 & 3.66 & 3.83 & 3.64 & 3.71 & 3.67 & 3.77 \\
\hline
\end{tabular}

Table 4: Solubilization Index of the 4 Phosphate Solubilizing Bacteria at $30^{\circ} \mathrm{C}$.

\begin{tabular}{|c|c|c|c|c|c|c|c|c|}
\hline Incubation day & $\mathbf{1}$ & $\mathbf{2}$ & $\mathbf{4}$ & $\mathbf{6}$ & $\mathbf{8}$ & $\mathbf{1 0}$ & $\mathbf{1 4}$ \\
\hline SI at $\mathbf{3 7}^{\circ} \mathbf{C}$ & 1 & 2 & 3 & 4 & 6 & 3.17 & 3.33 \\
\hline PSB4 & 2.8 & 3 & 3.2 & 3 & 3.33 & 3.5 \\
\hline PSB5 & 2.8 & 2.83 & 3 & 3.17 & 3.17 & 3.17 \\
\hline PSB6 & 2.8 & 3 & 2.83 & 3 & 3.33 & 3.21 \\
\hline Aci & 2.67 & 2.83 & 3 & 3.17 & 3.74 & 3.33 \\
\hline
\end{tabular}

Table 5: Solubilization Index of the 4 tested PSB at $37^{\circ} \mathrm{C}$. 


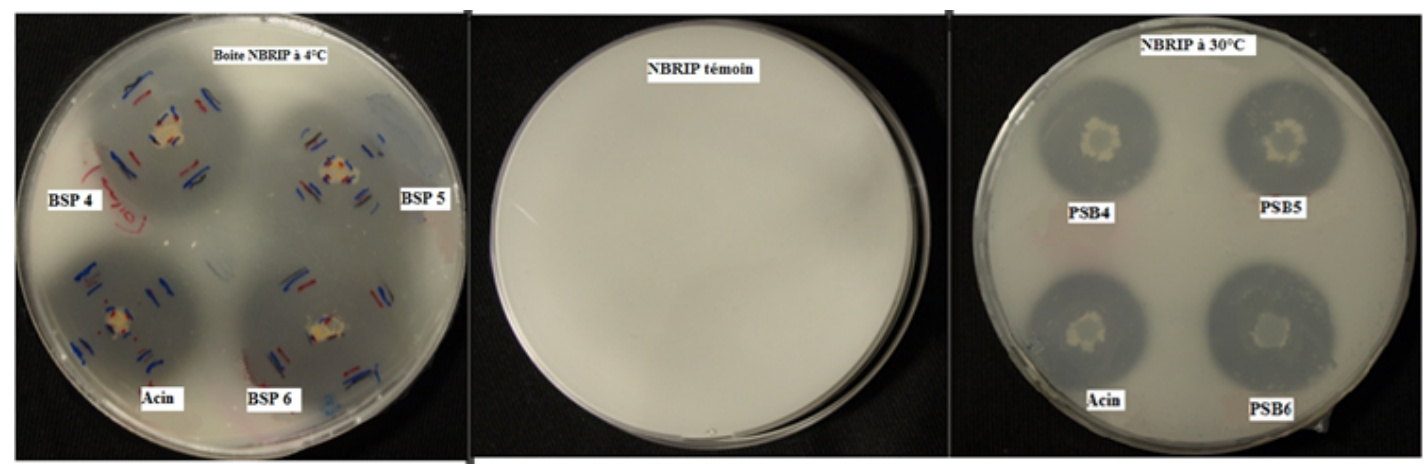

Figure 2: Solubilization halos by the four isolated bacterial strains (PBS4, PBS5, PBS6, Acin: Acinetobacter) on solid medium NBRIP before and after their conservation at $4^{\circ} \mathrm{C}$

concentration released by any PSB in comparison with the control (without the addition of EDTA). The PSB6 which produced $730.3 \mathrm{mg}^{-1}{ }^{-1} \mathrm{P}$, after adding $0.5 \mathrm{mg} \mathrm{ml}^{-1}$ EDTA could release just $600 \mathrm{mg}^{-1} \mathrm{l}^{-1}$, the PSB5 which release on the normal state $570.49 \mathrm{mg}^{-l^{-1}}$, released only 499.39 mg. $l^{-1} \mathrm{P}$.

The PSB4 produced only $470.8 \mathrm{mgl}^{-1}$ after producing under normal conditions $597.59 \mathrm{mg}^{-1} \mathrm{l}^{-1}$ of $\mathrm{P}$ in the extracellular medium, while the concentration of orthophosphate released by Acinetobacter sp. without the addition of EDTA was about $671.59 \mathrm{mg} \mathrm{l}^{-1}$, has been reduced to $430.3 \mathrm{mg} \mathrm{l}^{-1}$ after the addition of EDTA at $0.5 \mathrm{mg} \cdot \mathrm{ml}^{-1}$.

With the addition of $1 \mathrm{mg} \cdot \mathrm{ml}^{-1}$ EDTA, we observed increased levels of P released in comparison with those released when EDTA was added at $0.5 \mathrm{mg} \cdot \mathrm{ml}^{-1}$, but without outgoing to the same concentration of orthophosphate released by the controls (Figure 3). Increasing concentrations of EDTA added over than $1 \mathrm{mg} \cdot \mathrm{ml}^{-1}$, provoked a gradual decrease in phosphate solubilization, but without it complete inhibition even at a concentration of $10 \mathrm{mg} \cdot \mathrm{ml}^{-1}$ (EDTA).

The maximum level of soluble $\mathrm{P}$ was observed in the culture filtrate without EDTA. The level of soluble P decreased significantly when EDTA was amended to above $1.5 \mathrm{mg} \cdot \mathrm{ml}^{-1}$. During the study of Nautiyal et al. [29], it was noticed an increase in the amount of soluble phosphate produced by their PSB: NBRI0603, NBRI2601, NBRI3246 and NBRI4003, when the EDTA was added to the medium at a concentration of $0.5 \mathrm{mg} \cdot \mathrm{ml}^{-1}$ compared to the control, a result that was attributed to the chelation of $\mathrm{Ca}^{2+}$ ions liberated during the solubilization of TCP.

\section{Quantitative and qualitative analysis of organic acids pro- duced in culture with various carbon sources}

Acid production during phosphate solubilization appears to be an event of common occurrence. The organic acid production and phosphate solubilization in vitro by microbes is largely influenced by the carbon $(\mathrm{C})$ and nitrogen $(\mathrm{N})$ sources $[1,6-32,41]$.

The presence and the nature of nutrients are very important for the mechanism of $\mathrm{P}$ solubilization, since the concentration of organic acids produced is largely influenced by the substrates used [21]. To determine the nature of the organic acids produced by our bacteria during their growth with different carbon sources (glucose, fructose, galactose, maltose, and sorbitol), the supernatants were collected after the $\mathrm{pH}$ drop, filtered, and then injected to HPLC.

Analysis of chromatograms of different bacterial filtrates with different carbon sources was performed in comparison with our standard, and the results are shown in Table 3.

We noticed new organic acids in our bacterial supernatant, their presence was due to the changes of carbon sources, among these organic acids, we noted the 2 ketogluconic acid which was recorded by all bacterial strains and only when galactose was used as carbon source instead of glucose, except for Acinetobacter sp., the PSB5 was also able to produce the 2 ketogluconic acid in the presence of maltose and sorbitol in the culture medium (Table 3 ).

The absence of the 2 ketogluconic in cultures of Acinetobacter sp. is consistent with the results of the study of Gulati et al. [37] about Acinetobacter rhizosphaerae BIHB 723, which confirmed the absence of this O.A in the cultures of tricalcium phosphate and Udaipur Rock Phosphate with glucose as carbon source.

In general, the medium $\mathrm{pH}$ became reduced in all the treatments with time, the solubilization was accompanied with a decrease in $\mathrm{pH}$ from $7.0 \pm 0.2$ to $\mathrm{pH} 3.35,3.75,3.60$ and 3.55 for PSB6, PSB5, PSB4 and Acinetobacter sp. respectively, in normal conditions with glucose as carbon source and ammonium sulfate as a nitrogen source at $30^{\circ} \mathrm{C}$ for the $3 \mathrm{PSB}$ and $37^{\circ} \mathrm{C}$ for Acinetobacter sp. (Control).

We noticed a change in $\mathrm{pH}$ when these sources of carbon and nitrogen were different, although the only decrease in $\mathrm{pH}$ more than the control $\mathrm{pH}$ was noticed by the PSB5 in the presence of sorbitol as the sole carbon source, while the rest of the $\mathrm{pH}$ values varied between 3.41 and 4.57 for PSB6, 3.40 to 4.76 for PSB5, 3.68 to 4.51 for PSB4 and 3.55 to 5.35 for Acinetobacter sp. (Table 1).

The $\mathrm{pH}$ of the cultures with different concentrations of $\mathrm{NaCl}$, $\mathrm{pH}$ and temperature, also experienced some fluctuations, we noticed a decrease in the $\mathrm{pH}$ of the PSB6 3.35 (control) to 3.20 when it was cultured at $\mathrm{T}=37^{\circ} \mathrm{C}$ with high $[\mathrm{P}]$ released which happened to be $118.62 \%$.

The lactic acid was also detected at low concentrations in cultures of PSB4, PSB5 and PSB6 for all carbon sources used, except for Acinetobacter sp. that was only detected in the presence of fructose and maltose in the medium. It is an organic acid that is derived from the primary lactic fermentation called glycolysis, from the pyruvic acid too, and it has been previously mentioned in the literature being produced by the PSB: Bacillus amyloliquefaciens and Bacillus liqueniformis [42].

Glutaric acid was present in culture batches of PSB4 and PSB6 when fructose, galactose and sorbitol were used as a carbon sources. 
He was also in all PSB5 filtrate except that with glucose, as we couldn't notice its presence in Acinetobacter sp's cultures.

The fourth organic acid newly detected in our analysis is the Glucuronic acid, whose presence was recorded in PSB4 and PSB6 filtrates with different carbon sources except for glucose. It was also detected in fructose and sorbitol cultures with Acinetobacter and PSB5, plus in galactose filtrates for this last strain.
In addition to these newly identified organic acids in our bacterial filtrates, we could also detect the other O.A previously mentioned in our results [10], such as Gluconic acid (GA), a Ketoglutaric acid, glutamic acid and succinic acid (SA) were detected in all filtrates and with different carbon sources except for GA and SA in Acinetobacter which were not identified with sorbitol in the growth medium (Table 6).

Succinic acids result from the condensation of the oxalacetic acid

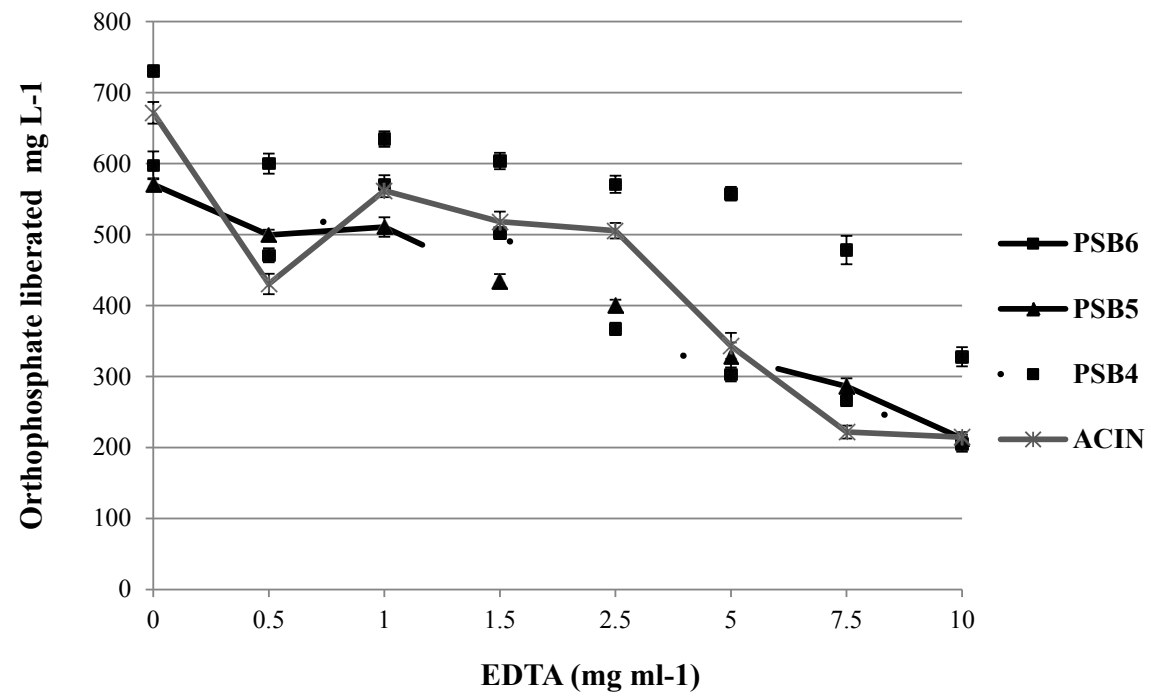

Figure 3: Effect of EDTA addition on phosphate solubilization by the four Phosphate Solubilizing Bacteria.

\begin{tabular}{|c|c|c|c|c|c|c|c|c|c|c|c|c|c|c|c|c|}
\hline $\begin{array}{l}P \\
S \\
B\end{array}$ & $\begin{array}{l}\text { Organic } \\
\text { acid con- } \\
\text { centration } \\
(\mathrm{mM})\end{array}$ & $\begin{array}{l}\text { Carbon } \\
\text { source }\end{array}$ & $\begin{array}{l}\text { Glu- } \\
\text { tamic } \\
\text { (GLA) }\end{array}$ & $\begin{array}{l}\text { Glu- } \\
\text { conic } \\
\text { (GA) }\end{array}$ & $\begin{array}{l}\text { Glucu- } \\
\text { ronic } \\
\text { (GLU) }\end{array}$ & $\begin{array}{c}\alpha \text {-ceto } \\
\text { glutaric } \\
(\alpha-K G A)\end{array}$ & $\begin{array}{c}2 \text { ceto } \\
\text { glu- } \\
\text { conic } \\
\text { (2CTA) }\end{array}$ & $\begin{array}{l}\text { Oxalo } \\
\text { acetic } \\
\text { (OXA) }\end{array}$ & $\begin{array}{l}\text { Malic } \\
\text { (MA) }\end{array}$ & $\begin{array}{l}\text { Pyruvic } \\
\text { (PA) }\end{array}$ & $\begin{array}{l}\text { Lactic } \\
\text { (LA) }\end{array}$ & $\begin{array}{c}\text { Glutaric } \\
\text { (GLT) }\end{array}$ & $\begin{array}{l}\text { Suc- } \\
\text { cinic } \\
\text { (SA) }\end{array}$ & $\begin{array}{c}\text { Fumaric } \\
\text { (FA) }\end{array}$ & $\begin{array}{c}\text { Acetic } \\
\text { (AA) }\end{array}$ & $\begin{array}{c}\text { Un- } \\
\text { known } \\
\text { organic } \\
\text { acids }\end{array}$ \\
\hline \multirow{5}{*}{6} & 252.83 & Glucose & + & + & - & + & - & + & + & + & + & - & + & + & + & $\mathrm{a}, \mathrm{c}, \mathrm{e}$ \\
\hline & 161.07 & Fructose & + & + & + & + & - & + & + & + & + & + & + & + & + & $a, b, c, d$ \\
\hline & 148.52 & $\begin{array}{l}\text { Galac- } \\
\text { tose }\end{array}$ & + & + & + & + & + & + & + & - & + & + & + & + & + & $a, b, c, e$ \\
\hline & 104.87 & Maltose & + & + & + & + & - & + & + & + & + & - & + & + & + & $a, b, c$ \\
\hline & 102.65 & Sorbitol & + & + & + & + & - & + & + & - & + & + & + & + & + & $a, b, c$ \\
\hline \multirow{5}{*}{5} & 133.12 & Glucose & + & + & - & + & - & + & + & + & + & - & + & + & - & $a, c, e$ \\
\hline & 101.33 & Fructose & + & + & + & + & - & + & + & - & + & + & + & + & + & $\begin{array}{c}a, b, c \\
d, f\end{array}$ \\
\hline & 140.43 & $\begin{array}{c}\text { Galac- } \\
\text { tose }\end{array}$ & + & + & + & + & + & + & + & - & + & + & + & + & + & $a, b, c$ \\
\hline & 104.66 & Maltose & + & + & - & + & + & + & + & - & + & + & + & + & + & $a, b, c$ \\
\hline & 112.37 & Sorbitol & + & + & + & + & + & + & + & - & + & + & + & + & - & $a, b, c, d$ \\
\hline \multirow{5}{*}{4} & 126.90 & Glucose & + & + & - & + & - & + & + & + & + & - & + & - & + & $a, c, e$ \\
\hline & 114.01 & Fructose & + & + & + & + & - & + & + & - & + & + & + & + & + & $a, b, c, d$ \\
\hline & 142.60 & $\begin{array}{l}\text { Galac- } \\
\text { tose }\end{array}$ & + & + & + & + & + & + & - & - & + & + & + & + & - & $a, b, c, e$ \\
\hline & 131.55 & Maltose & + & + & + & + & - & + & + & - & + & - & + & + & + & $a, b, c$ \\
\hline & 85.70 & Sorbitol & + & + & + & + & - & + & + & - & + & + & + & + & + & $a, b, c$ \\
\hline \multirow{5}{*}{ Aci } & 164.12 & Glucose & + & + & - & + & - & + & + & + & - & - & + & + & + & $\mathrm{a}, \mathrm{c}, \mathrm{e}$ \\
\hline & 103.88 & Fructose & + & + & + & + & - & - & + & + & + & - & + & + & - & $a, b, c, e$ \\
\hline & 139.08 & $\begin{array}{l}\text { Galac- } \\
\text { tose }\end{array}$ & + & + & - & + & + & + & - & + & - & - & + & + & + & $a, b, c$ \\
\hline & 120.04 & Maltose & + & + & - & + & - & + & + & + & + & - & + & + & + & $a, b, c$ \\
\hline & 73.81 & Sorbitol & + & - & + & + & - & - & + & - & - & - & - & - & + & $a, b, c$ \\
\hline
\end{tabular}

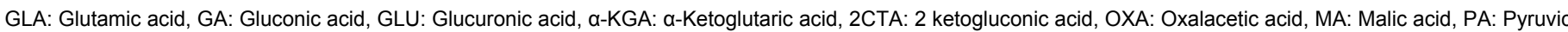
acid, LA: Lactic acid, GLT: Glutaric acid, SA: Succinic acid, FA: Fumaric acid, AA: Acetic acid. Plus or minus means organic acid detected (+) or not detected (-). $\mathrm{a}, \mathrm{b}, \mathrm{c}, \mathrm{d}, \mathrm{e}$, and f: Unknown organic acids detected, respectively, at the following retention times $(\mathrm{min}): 7.7 \pm 0.1,10.9 \pm 0.1,18.8 \pm 0.1,19.3 \pm 0.1,21.5 \pm 0.1,24.7 \pm 0.1$.

Table 6: Quantitative and qualitative analysis of organic acids produced by the 4 PSB using HPLC. 
with the acetyl CoA in the cycle of Krebs. This last one (OXA) was also detected on the filtrates of the four PSB, except for Acinetobacter when fructose and sorbitol were used as carbn sources (Table 6).

Fumaric and acetic acid were identified in cultures of the PSB6 with different carbon sources. Unlike PSB4 and PSB5, the appearance of an acid does not coincide with the appearance of the other, since cultures of PSB5 containing glucose did not produce AA, whereas PSB4 didn't produce FA. While those two O.A were also produced by Acinetobacter sp. using glucose as sugar.

For other carbon sources, the AA was absent in cultures of: PSB5 with Sorbitol, PSB4 with galactose and in Acinetobacter sp. filtrates with Fructose. While the FA was present in all other supernatants except the one of Acinetobacter sp. with sorbitol as carbon source. Note that the biosynthesis of AA is through acidic fermentation by sugar incomplete oxidation.

Quantifying the concentration of organic acids produced by our bacterial strains, revealed different concentrations depending on the nature of carbon sources used but also on the nature of the bacteria used (Table 3). Increased concentrations of O.A produced by all the PSB in presence of glucose as carbon source at optimal conditions has been demonstrated, since PSB6 produced a quantity of $252.83 \mathrm{mM}$, after adopting inoculums containing medium LB + TCP.

This was also the case for the PSB5 and PSB4 with concentrations of O.A that have reached $133.12 \mathrm{mM}$ and $126.90 \mathrm{mM}$ respectively, while Acinetobacter sp was able to produce a little more reaching $164.12 \mathrm{mM}$ (Table 3). HPLC analysis showed that the acidification of extracellular medium of different bacterial cultures was perhaps due to the conversion of different sugars in their respective Aldonic acids by direct oxidation through GDH enzyme.

Priory reports have demonstrated the use of different carbon sources to determine the optimal conditions for P solubilization; it is the case of the study of Sharma et al. [43] which highlighted the simultaneous action of GDH on various sugars to produce enough acids. Since the results suggested that the acidification induced by the GDH action is the main mechanism for the phospho-solubilization by Enterobacter asburiae PSI 3 and that the aldonic acids generated by the action of the same enzyme (GDH) on different sugars caused and induced the P solubilization.

In conclusion, the results suggest that the bacterial strains PSB6, PSB5 and PSB4 isolated from Moroccan phosphate deposit and also our positive control Acinetobacter sp. have demonstrated their ability to solubilize phosphate (TCP) in the presence of high salt concentration, high $\mathrm{pH}$, and at different temperatures.

These bacteria can be used as an excellent model to study the biochemical, physiological and molecular mechanisms of phosphate solubilization in stressed ecosystems.

They can also be used as a bacterial host to propagate new or improved characters for ecosystems having problems of high salt, $\mathrm{pH}$ or temperature. The availability of adequate and appropriate $\mathrm{C}$ sources in the soil is known to be a limiting factor for the survival, growth and functioning of microorganisms in soils.

Generally, the rhizospheric soil is richer in carbon source, since the plants secrete about $5 \%-21 \%$ of carbon through root exudates $[25,44]$. It was suggested that a microorganism that is capable of using a variety of carbon source for its bioenergy, may have an advantage over other microorganisms that are limited by their carbon sources in their natural environments $[43,45]$.

The versatile use of different carbon sources for $\mathrm{P}$ solubilization by our PSB may therefore be significant from the perspective of their field performance.

Since soil conditions are much more complex than in vitro, further study of the environmental factors affecting phosphate solubilization in soils should be a basis for obtaining inoculants that are able to provide greater phosphate solubilization for crops of economic or agricultural importance in different areas.

\section{Acknowledgments}

This research was funded by the program of AECID (Agencia Española de Cooperación Internacional, MAEC, Spain) through a PhD Fellowship to Miss Ilham Mardad. Partial support of BIO-261 group (PAIDI, Junta de Andalucia) is also acknowledged. IBVF is part of the CeiA3 and AndaluciaTech University Campuses of Scientific Excellence. The authors are grateful to Pr. Emna Ammar for her help on correcting the paper and to Mr. Carlos Parejo for his help in monitoring HPLC apparatus.

\section{References}

1. Rodríguez H, Fraga $\mathrm{R}$ (1999) Phosphate solubilizing bacteria and their role in plant growth promotion. Biotechnol Adv 17: 319-339.

2. Kucey RMN, Jenzen HH, Leggett M (1989) Microbially mediated increases in plant available phosphorus. Adv Agron 42: 199-228.

3. Sperber JI (1957) Solution of mineral phosphates by soil bacteria. Nature 180 994-995.

4. Khan MS, Zaidi A, Wani PA (2009) Role of Phosphate Solubilizing Microorganisms in Sustainable Agriculture - A Review. Sustain Agric 551-570.

5. Surange S, Wollum II AG, Kumar N, Nautiyal CS (1997) Characterization of Rhizobium from root nodules of leguminous trees growing in alkaline soils. Can J Microbiol 43: 891-894.

6. Subba Rao NS (1982) Phosphate solubilization by soil microorganisms Advances in Agricultural Microbiology, Butterworth Sci, London, UK.

7. Walker TS, Bais HP, Grotewold E, Vivanco JM (2003) Root exudation and rhizosphere biology. Plant Physiol 132: 44-51.

8. Yahya Al, Al-Azawi SK (1989) Occurrence of phosphate solubilizing bacteria in some Iraqi soils. Plant Soil 117: 135-141.

9. Pal SS (1998) Interactions of an acid tolerant strain of phosphate solubilizing bacteria with a few acid tolerant crops. Plant Soil 198: 169-171.

10. Mardad I, Serrano A, Soukri A (2013) Solubilization of inorganic phosphate and production of organic acids by bacteria isolated from a Moroccan minera phosphate deposit. Afr J Microbiol Res 7: 626-635.

11. Tamura K, Dudley J, Nei M, Kumar S (2007) MEGA4: Molecular Evolutionary Genetics Analysis (MEGA) software version 4.0. Mol Bio Evol 24: 1586-5589.

12. Nautiyal CS (1999) An efficient microbiological growth medium for screening phosphate solubilizing microorganisms. FEMS Microbiol Lett 170: 265-270.

13. Afnor (1994) Recueil des normes Françaises Eau, Méthodes d'essais. Paris, France.

14. Edi-Premono M, Moawad MA, Vleck PLG (1996) Effect of phosphate solubilizing Pseudmonas putida on the growth of maize and its survival in the rhizosphere. Indonesian J Crop Sci 11: 13-23.

15. Venkateswarlu B, Rao AV, Raina $P$ (1984) Valuation of $P$ solubilization by microorganisms isolated from arid soils. J Indian Soc Soil Sci 32: 273-277.

16. Hwangbo H, Park RD, Kim YW, Rim YS, Park KH et al. (2003) 2-ketogluconic acid production and phosphate solubilization by Enterobacter intermedium. Curr Microbiol 47: 87-92.

17. Kumar A, Bhargava P, Rai LC (2010) Isolation and molecular characterization of phosphate solubilizing Enterobacter and Exiguobacterium species from paddy fields of Eastern Uttar Pradesh, India. Afr J Microbiol Res 4: 820-829.

18. Park JH, Bolan N, Megharaj M, Naidu R (2011) Concomitant rock phosphate 
Citation: Mardad I, Serrano A, Soukri A (2014) Effect of Carbon, Nitrogen Sources and Abiotic Stress on Phosphate Solubilization by Bacterial Strains Isolated from a Moroccan Rock Phosphate Deposit. J Adv Chem Eng 1: 102. doi: 10.4172/2090-4568.1000102

dissolution and lead immobilization by phosphate solubilizing bacteria (Enterobacter sp.) J Environ Manage 92: 1115-1120.

19. Shankar M, Ponraj P, llakkiam D, Gunasekaran P (2011) Root colonization of a rice growth promoting strain of Enterobacter cloacae. J Basic Microbiol 51 $523-530$

20. Dave A, Patel HH (2003) Impact of different carbon nitrogen sources on phosphate solubilization by Psedomonas fluorescens. Indian J Microbiol 43: 33-36.

21. Narsian V, Patel HH (1995) Inorganic phosphate solubilization by some yeasts. Indian J Microbiol 35: 127-132.

22. Gaur AC (1990) Phosphate solubilizing microorganisms as biofertilizers. Omega scientific Publishers.

23. Barroso CB, Pereira GT, Nahas E (2006) Solubilization of CaHPO4 and A PO4 by Aspergillus Niger in culture media with different carbon and nitrogen sources. Brazilian J Microbiol 37: 434-438.

24. Thakker J, Narsian V, Patel HH (1993) Inorganic phosphate solubilization by certain soil bacteria. Indian J Exp Biol 31: 743-746.

25. Brock TD, Madigan MT, Martinko JM, Parker J (1994) Biology of microorganisms. Prentice, New Jersey.

26. Illmer P, Schinner F (1995) Solubilization of inorganic calcium phosphatessolubilization mechanisms. Soil Biol Biochem 27: 257-263.

27. Asea PEA, Kucey, RMN, Stewart JWB (1988) Inorganic phosphate solubilization by two Penicillium species in solution culture and soil. Soil Biol Biochem 20: 459-464.

28. Whitelaw MA (2000) Growth promotion of plants inoculated with phosphatesolubilizing fungi. Adv Agron 69: 99-151.

29. Nautiyal CS, Bhadauria S, Kumar P, Lal H, Mondal R et al. (2000) Stress induced phosphate solubilization in bacteria isolated from alkaline soils. FEMS Microbiol Lett 182: 291-296.

30. Abd-Alla MH (1994) Solubilization of rock phosphate by rhizobacterium and Bradyrhizobacterium. Folia Microbiol 39: 53-56.

31. Halder AK, Mishra AK, Chakrabartty PK (1991) Solubilization of inorganic phosphate by Bradyrhizobium. Indian J Exp Biol 29: 223-229.

32. Pradhan N, Sukla LB (2005) Solubilization of inorganic phosphates by fung isolated from agriculture soil. Afr J Biotechnol 5: 850-854.
33. Roos W, Luckner M (1984) Relationships between Proton Extrusion and Fluxes of Ammonium lons and Organic Acids in Penicillium cyclopium. J Gen Microbio 130: $1007-1014$

34. Bolan NS, Ellott J, Gregg PEH, Weil S (1997) Enhanced dissolution of phosphate rocks in the rhizosphere. Biol Fert Soils 24: 169-174.

35. Thomas GV, Shantaram MV, Saraswathy N (1985) Occurence and ability of phosphate-solubilizing fungi from coconut plant soils. Plant Soil 87: 357-364.

36. Karunai Selvi B, Ravindran AD (2012) Influence of different carbon and nitrogen sources on insoluble inorganic phosphate solubilization by Bacillus subtilis. Int J Adv Bio Res 2: 441-445.

37. Gulati A, Sharma N, Vyas P, Sood S, Rahi P et al. (2010) Organic acid production and plant growth promotion as a function of phosphate solubilization by Acinetobacter rhizosphaerae strain BIHB 723 isolated from the cold deserts of the trans-Himalayas. Arch Microbiol 192: 975-983.

38. Chen YP, Rekha PD, Arun AB, Shen FT, Lai WA et al. (2006) Phosphate solubilizing bacteria from subtropical soil and their tricalcium phosphate solubilizing abilities. Appl Soil Ecol 34: 33-41.

39. El-Komy MAH (2005) Coimmobilization of Azospirillum lipoferum, Bacillus megaterium for Successful Phosphorus, Nitrogen Nutrition of Wheat Plants. Food Technol Biotechnol 43: 19-27.

40. Gaur AC, Madan M, Ostwal KP (1973) Solubilization of phosphatic compounds by native micro flora of rock phosphates. Indian J Exp Biol 11: 427-429.

41. Cunningham JE, Kuiack C (1992) Production of citric and oxalic acids and solubilization of calcium phosphate by Penicillium bilaii. Appl Environ Microb 58: $1451-1458$

2. Bano N, Musarrat $\mathrm{J}$ (2004) Characterization of a novel carbofuran degrading Pseudomonas sp. with collateral biocontrol and plant growth promoting potential. FEMS Microbiol Lett 231: 13-17.

43. Sharma V, Kumar V, Archana G, Kumar GN (2005) Substrate specificity of glucose dehydrogenase (GDH) of Enterobacter asburiae PSI3 and rock phosphate solubilization with GDH substrates as $\mathrm{C}$ sources. Can J Microbiol 51: 477-482.

44. Matsushita K, Ameyama M (1982) D-glucose-dehydrogenase from Pseudomonas fluorescens, membrane bound. Methods Enzymol 89: 149-154.

45. Goodwin PM, Anthony C (1998) The biochemistry physiology and genetics of $P Q Q$ and $P Q Q$ containing enzymes. Adv Microb Physiol 40: 1-69. 